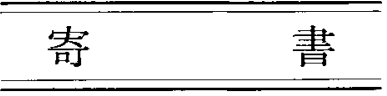

\title{
浅野らの“電解水素チャージによる鉄鋼の固溶硬化と
}

\section{異常軟化現象”論文でよせられた高純度鉄の 水素チャージによる軟化についての批判への回答}

(Reply to the Comment made by Asano et al. on the Hydrogen Induced Softening in High Purity Iron in their Paper, "Lattice Hardening and Anomalous Softening of Iron and Steel Caused by Electrolytic Hydrogen Charging".)

木村 宏* 松井秀樹* 森谷信義** 木村晃彦***

(Hiroshi Kimura, Hideki Matsui, Shingi Moriya and Akihiko Kimura)

浅野ら (1)は表題の論文において，鉄鋼の変形㐫力に対す る電解水素チャージの効果を慎重に検討し，鉄鋼に叔いて は水素チャージにより硬化するのが本質的効果であり，軟 化は電解水素チャージ中におこる表面層での水素析出に伴 ら転位発生が原因である副次的効果であると結論した。電

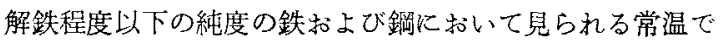
の水素チャージによる軟化は，主として水素析出に伴ら試 料の摜賃が原因であることは，羽木ら (2)によっても実証さ れて拈りこの種の研究においては，試料の椇傷による副 次的効果を分離しなければならないという浅野らの指摘は 諴に当を得たるのと言えよう。

一方，われわれ，高純度鉄に水素チャージするといちじ るしい軟化の报こることを見出し(3)，これは水素チャ一ジ に伴ら損傷によるすのではなく本質的效果であることを繰 遮し述べて来た (4)〜6). しかし浅野らはこの高純度鉄にお ける軟化名損傷が原因で需るとして説明できると論じてい るので，改めてわれわれの実験結果を要䄪し，この軟化が 本犋的効果であることを述べ，浅野らの批判に答えたい。

われわれは引張試験中に水素チャージを行ら方法と並行 して，常温で水素チャージを行ってから低温 $(77 \sim 260 \mathrm{~K}$ ) の非電解質溶液中に試料を急冷し(もらろ九電弫も印加し ない，引張試験を行った。その結果，190 K 以下では硬 化， $200 \mathrm{~K}$ 以上では軟化のおこることを見神した。この硬 化ならびに軟化の温度範畍は，水薪チャージを行いつつ引! 張試験を行った場合に見られる硬化ならびに軟化の温度範 囲と一致し，敷化量もほぼ同程度であった。このよらなチ ャージ後の実験では，チャージにより試料中に導入された 固溶水素はほとんどすべて表面から放出されていることが
確琶されているので(7)，浅野らの言うような水素析出なら びに転位の供維は全くおこっていないはずである。この軟 化（拈よび $190 \mathrm{~K}$ 以下での硬化）は，転位柋に捕獲されて 残っている水素が原因であると考えざるを得ない。また， チャージ中抗びチャージ後のいずれの実験に秃いても， 低純度の鉄は軟化の程度が小さ，さらに条件によっては 硬化を示した，たとえば，浅野らとほ汪同じ電解液を用い $20 \mathrm{~A} / \mathrm{m}^{2}$ の電流密度で水素チャージしつつ常温で試験する と, 残留抵抗比 3500 以上の高純度鉄は軟化するが，それ より純度の低いジョンソンマッセ一鉄 (JM 鉄, 残留抵抗比 1500)は硬化した。しかも，高練度鉄では表面にブリスタ 一ははとんど珰められなかったが，JM 鉄ではかなりの数 が弪められた。すなわら，水素チャージによる損傷の認め られなかったものは軟化し，損賃の橤められたすのは硬化 した。これは浅野らの説から期待されることとは逆の結果 である。

もちろん，浅野らの指摘しているよ5に，13Cr 堸など のように合金濃度が高くて固溶硬化をおこしているるので は，表面のクラックが微細で観察が難しいから，単なる表 面観察から損㑺の有無は論じられないかも知れない、しか しここで比較しているのは，JM 鉄とそれよりさらに高純 度の鉄であり，常温での降伏応力は活とんど变りない軟ら かい材料である。したがって，表面ブリスターの有無は損 㑑の有無と解してよるしいであろら。われわれはさらに， 電気抵抗測定，透過電顕法によっても調べたが，JM 鉄の 方が常に損傷を生じやすかった。ただしJM 鉄の場合でも その損傷の程度はそれによって軟化が生ずるほど大きいも のではないので,ブリスターを生じても硬化するのである

* 東北大学金属材料研究所 (The Research Institute for Iron, Steel and Other Metals, Tohoku University, Sendai)

** 東北大学大学院, 現在：日本金属工業株式会社衣浦製造所 (Graduate School, Tohoku University， Sendai. Present address : Kinu-ura Works, Nippon Metal Industry Co., Hekinan)

*** 東北大学大学院 (Graduate School, Tohoku University, Sendai) 
ら。この JM 鉄にお汓る硬化は，浅野上の見出している電

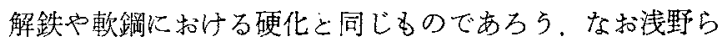
は応力緩和法に上って水素チャージ沉るる損傷を検出でき るとしている。水素千ャ一ジにより損傷が括こり可動転位 が供絈されれれ゙，いったん停比した応力緩和が再びおこる ことはたしかである。しかし，新しく転位が供給されなく て子，水素チャージによってらせん転位が動きやすくなれ ば，それでも現象的には同じことがおこるはずである。し たがって，応力緩和の促進があれば乞れは損傷のためであ ると一義的に結論することはでをない，

第3に，高純度鉄の軟化量の電流密度低存性を調べたと ころ，要る霄流密度 (たとえば $0.4 \mathrm{~mm}$ 径の試料で $20 \mathrm{~A} / \mathrm{m}^{2}$ ) を栈えると，軟化量注汪ぼ一定，るしくはやや減少するよ らになった。るしも水素チャージによる損傷が原因である ならば，電流密度の大きい汪と軟化量も大き?なるである らから，この結果は損傷が軟化の原因であるとする考元に は不都合である。これに対しては損傷説の立場から，20 $\mathrm{A} / \mathrm{m}^{2}$ では電流密度が大きすぎ転位が多く発生しその相互 作用に上って硬化の傾向があらわれたのであららしいう反 論があるかも知れない。しかし，浅野らは $0.0 . \mathrm{mm}$ 厚の 試料で $50 \mathrm{~A} / \mathrm{m}^{2}$ まで軟化を見出しているのであるから， このような反論は成立しない。第 4 点として，浅野らは軟 鋼試料については $0.2 \mathrm{~mm}$ 以上の厚さでは硬化を見出し, これが表面損傷效果による軟化を無視でさる厚さであるる てているが，われわれが一般に用いている高純度試料は直 径 $0.4 \mathrm{~mm}$ であり，さらに $1 \mathrm{~mm}, 2 \mathrm{~mm}$ 径のものでも軟 化を見出している(5)。これは浅野らの言う十分にバルクの 効果を検出できる太さだと考交てよいであるら。第5に透 渦電影観察に上ると，水素チャージしたものの方がいくら か転位密度が大きいが，観測される大きな赖化量を挽明で きるほどの転位密度の増加ではなかった。転位の供給で軟 化を説明するとすれば，羽状転位が供給されるとしなけれ ばならないが，転位組織の観察からこのことを皘極的に支 持する結果は得られなかった。

以上の 5 点は，約 $200 \mathrm{~K}$ 以上常温附近まで見られる高 純度鉄の水素チャージによる軟化は，水素析出に伴う損傷 による副次的効果ではなく，本質的効果であることを示し ている，低純度の鉄および鋼で見出された軟化とは，チャ 一ジ電流の ON, OFF に対して可逆的であるという点では 現象的に似てはいるが，実は全く異望なものである。低純
度の鉄㧍よび鋼における䧈化を異常と呼ら゙ことはそれなり に理由のあることであるが，高純度鉄に拈ける軟化はけっ して異常ではなく，本質的効果である。この点は明確に区 別されるべきである，さらに，われわれの高純度鉄中の固 溶不純物量恃残留抵抗比 ${ }^{(8)}$ ，質量分析 ${ }^{(9)}$ の結果加䄪 10 at.ppm と推定され，電解チャージによる固溶水素量はこ れを上まわっていると考光られるから(1)(7)，高純度鉄での 軟化は鉄本来のものであり，転位と水素之の直接的相互作 用によっていると解釉されるべきすのであるら。これに対 し，電解鉄や鋼に扎いては不純物量が固溶水素量を上委わ っており，これらの材料に扣いて見られる硬化が本質的効 果であることは疑いないとしても，この硬化は転位と水素 の少の相互作用としてではなく，転位と水素と不純物の 3 者の相互作用によるとして解釈されるべきで努う5。なお 高純度鉄に怙いて約 $190 \mathrm{~K}$ 以下で見られる硬化怯，やは り本質的なるのであり，鞋位の刃状成分と水素との相互作 用の結果として解积できる。この硬化についてはほとんど 説明しなかったが，不純な鉄扔よび鋼における硬化之は一 応区別しておくべきであるう。

\section{文南}

（1）浅野 滋，西野洋一，大塚陸郎：日本金属学会誌， $43(1979), 241$.

（2）羽木秀樹，林 安㯖，大行南海男：日本金属学会 誌, $42(1978), 124$.

(3) H.Matsui, S.Moriya and H.Kimura : The Strength of Metals and Alloys, Proc. 4 th Int. Conf. Nancy-France, Vol.1(1976), 291.

(4) H.Kimura, H.Matsui and S.Moriya : Scripta Met., 11 (1977), 473.

(5) H.Kimura and H.Matsui; Scripta Met., 13 (1979) , 221.

（6）松井秀樹，森谷信義，木村晃彦，木村宏：日本金 属学会講演慨要集, $(1976 \cdot 10$ 月), 281 ; (1977·4月), 186 ; (1977·10月), 222 ( 2 篇); (1978·10月), 146. 金 属学会シンボジゥム“金属と本素”(1978.11月), $5,9$.

(7) S.Moriya,S.Takaki and H.Kimura: Mat.Sci. Eng., 32(1978), 71.

(8) S. Takaki and H.Kimura : Scripta Met., (1976), 1095.

(9) S.Takaki, S.Suzuki and H.Kimura: to be published. 